\title{
Hubungan antara hipertensi dengan albuminuria pada usia 40-70 tahun
}

\author{
Kamia Puspita Sardi ${ }^{1}$ Pusparini $^{2}$
}

\begin{abstract}
ABSTRAK
\section{LATAR BELAKANG}

Hipertensi merupakan penyakit kronis yang sering ditemukan seiring dengan peningkatan usia. Penyakit ini membutuhkan kontrol tekanan darah secara optimal dan merupakan faktor risiko terjadinya gagal ginjal tahap akhir atau end-stage renal disease (ESRD). Pada penderita hipertensi salah satu petanda adanya kebocoran pada ginjal adalah dengan dijumpainya albuminuria. Tujuan penelitian ini adalah untuk mengetahui hubungan antara hipertensi dengan albuminuria.
\end{abstract}

\section{METODE}

Penelitian ini merupakan penelitian dengan desain potong lintang mengikutsertakan 40 responden. Data diambil dari rekam medis dari bulan Desember 2014-Desember 2015 di salah satu rumah sakit swasta di Jakarta Pusat. Kriteria inklusi adalah pria dan wanita usia 40-70 tahun, menderita hipertensi, dan pada rekam medis terdapat data tekanan darah dan hasil albuminuria. Kriteria eksklusi adalah data rekam medis tidak lengkap, menderita diabetes melitus, gagal jantung dan menderita infeksi saluran kemih. Analisis data dilakukan dengan menggunakan uji Spearman dengan tingkat kemaknaan $\mathrm{p}<0.05$.

\section{HASIL}

Usia subjek yang paling dominan adalah usia 50-59 tahun (37.5\%), dengan jenis kelamin sama banyak antara pria dan wanita masingmasing 50\%. Subjek dengan derajat hipertensi terbanyak yaitu hipertensi derajat $2(37.5 \%)$ dan nilai albuminuria yang dominan adalah negatif. Hasil uji Spearman menunjukkan terdapat korelasi yang bermakna antara hipertensi dengan albuminuria $(\mathrm{r}=0.428, \mathrm{p}=0.006)$.

\section{KESIMPULAN}

Terdapat korelasi yang bermakna antara hipertensi dengan albuminuria yang menunjukkan bahwa semakin tinggi tekanan darah pada pasien hipertensi, maka semakin besar kadar albuminuria.

Kata kunci : hipertensi, albuminuria, gagal ginjal tahap akhir
${ }^{1}$ Program Studi Kedokteran,

Fakultas Kedokteran, Universitas Trisakti

${ }^{2}$ Departemen Patologi Klinik, Fakultas Kedokteran, Universitas Trisakti

\section{Korespondensi:}

Pusparini

Departemen Patologi Klinik, Fakultas Kedokteran, Universitas Trisakti, Jalan Kyai Tapa No. 260, Grogol, Jakarta Barat Email: pusparini@trisakti.ac.id

\author{
J Biomedika Kesehat 2019;2(1):3-9 \\ DOI: $10.18051 /$ JBiomedKes.2019. \\ v2.3-9
}

pISSN: 2621-539X / eISSN: 2621-5470

Artikel akses terbuka (open access) ini didistribusikan di bawah lisensi Creative Commons Attribution 4.0 International (CC-BY 4.0) 


\section{ABSTRACT}

\section{Correlation between hypertension and albuminuria in 40-70 years old}

\section{BACKGROUND}

Hypertension is a chronic disease that often find with increasing age. Hypertension requires optimal control and a strong independent risk factor for the occurrence of end-stage renal disease (ESRD). In hipertension patient, one of marker for renal failure is albuminuria. The aim of this study was to determine correlation between hipertension and albuminuria.

\section{METHODS}

This study was a cross sectional design. Samples obtained were 40 respondents at one of private hospital at Central Jakarta. This research use medical records from December 2014-December 2015. The inclusion criteria were male and female 40-70 years old, hipertension, and have record of blood pressure and albuminuria at medical record. The exclusion criteria were the medical record not complete, have diabetes mellitus, cardiac failure and have infection urinary tractus. The data were analyzed using Spearman test with significancy $\mathrm{p}<0.05$.

\section{RESULT}

The dominant age were 50-59 years old $(37.5 \%)$, while the percentage of women are equal with men $(50 \%)$. The highest number of hypertension was the 2 nd degree hypertension $(37.5 \%)$ and the albuminuria was dominated with negative result. There were a significant correlation between hypertension and albuminuria $(r=0.428, p=0.006)$.

\section{CONCLUSION}

There were significant correlation between hypertension with albuminuria, suggested that the more higher of blood pressure in patients with hypertension the more increase albuminuria.

Keywords : hypertension, albuminuria, end stage renal disease

\section{PENDAHULUAN}

Hipertensi didefinisikan sebagai tekanan darah sistolik $140 \mathrm{mmHg}$ (millimeter hydrargirum) atau lebih tinggi dan atau tekanan darah diastolik $90 \mathrm{mmHg}$ atau lebih tinggi. ${ }^{(1)}$ Hasil riset kesehatan dasar(Riskesdas) 2007 yang dilakukan di Indonesia menunjukkan bahwa proporsi penyebab kematian tertinggi adalah penyakit tidak menular (PTM) yaitu penyakit kardiovaskuler $(31.9 \%)$ termasuk hipertensi dan stroke. ${ }^{(2)}$ Terjadi peningkatan prevalensi hipertensi dari 7.6 persen pada tahun 2007 menjadi 9.5 persen pada tahun 2013. Prevalensi hipertensi di Indonesia berdasarkan hasil pengukuran pada umur $\geq 18$ tahun sebesar 25.8 persen. Prevalensi hipertensi juga dilaporkan makin meningkat seiring dengan meningkatnya usia. Usia hipertensi paling sering dijumpai adalah usia 40 tahun ke atas. ${ }^{(2)}$

Hipertensi merupakan penyakit kronis yang sering dijumpai tanpa adanya gejala klinis dan membutuhkan kontrol optimal serta kepatuhan terus-menerus untuk mengonsumsi obat sehingga dapat mengurangi komplikasi kardiovaskular, serebrovaskular maupun penyakit ginjal. ${ }^{(3)}$ Tekanan darah yang tinggi dapat berupa penyebab atau konsekuensi dari penyakit ginjal kronik (PGK). Tekanan darah yang tinggi dapat pula berkembang di awal perjalanan PGK dan dapat dikaitkan dengan hasil yang merugikan seperti memburuknya fungsi ginjal dan perkembangan penyakit kardiovaskular. Penelitian Ravera et $\mathrm{al}^{(4)}$ menunjukkan hipertensi merupakan faktor risiko independen yang kuat untuk terjadinya penyakit ginjal tahap akhir atau end-stage renal disease (ESRD). ${ }^{(4)}$ Hubungan antara tekanan darah albuminuria dan disfungsi renal merupakan suatu kondisi dilema antara mana yang lebih dahulu terjadi, apakah telur dahulu atau ayam lebih dahulu (chicken or egg dilemma). ${ }^{(5)}$

Proteinuria adalah manifestasi paling umum dari penyakit ginjal. Definisi proteinuria menurut National Institute of Diabetes and Digestive and Kidney Disease (NIDDK) adalah sebuah keadaan dimana terdapatnya komponen protein dalam kandungan urin. ${ }^{(6)}$ Komponen protein dalam urin yang paling sering adalah albumin, yang akan meningkat sejalan dengan meningkatnya kerusakkan pada pembuluh darah baik ginjal maupun jantung. ${ }^{(7)}$ Hasil dari sejumlah penelitian eksperimental menunjukkan bahwa albuminuria tidak hanya merupakan tanda kerusakan ginjal, tetapi juga berpartisipasi dalam perkembangan penyakit ginjal. ${ }^{(8)}$ Untuk mendeteksi adanya albuminuria dapat dilakukan dengan tes dipstick. (9) Tes dengan dipstick merupakan tes yang mudah dilakukan di seluruh fasilitas kesehatan. Riskesdas 2013 juga melaporkan cakupan tenaga kesehatan 
di Indonesia untuk mendeteksi hipertensi hanya $36.8 \%$ sedangkan sebagian besar masyarakat yaitu $63.2 \%$ kasus hipertensi tidak terdiagnosis. (2) Pemeriksaan albuminuria yang mudah dan murah dilakukan dapat membantu masyarakat untuk meningkatkan kewasapadaan terdapatnya hipertensi yang dapat menyebabkan terjadinya kerusakkan ginjal. Penelitian Yoon et al ${ }^{(9)}$ di Korea menunjukkan kelompok non obese dan yang mempunyai lingkar perut normal lebih sering menderita hipertensi tetapi mempunyai kontrol buruk baik pada kelompok mikroalbuminuria maupun makroalbumiuria. ${ }^{(9)}$ Sebaliknya penelitian Jessani et $\mathrm{al}^{(10)}$ menunjukkan bahwa albuminuria dalam batas normal tinggi dapat memprediksi keadaan hipertensi. ${ }^{(10)}$ Tujuan penelitian ini adalah untuk mengetahui hubungan antara hipertensi dengan albuminuria pada usia 40-70 tahun.

\section{METODE}

Penelitian ini merupakan penelitian dengan desain potong lintang. Subjek penelitian ini adalah pasien dewasa yang berobat di salah satu rumah sakit di Jakarta Pusat. Data yang diambil merupakan data sekunder dari data rekam medis antara bulan Desember 2014 sampai dengan Desember 2015. Besar sampel minimal berdasarkan perhitungan dengan menggunakan rumus adalah 23 subjek dengan nilai $r=0.55^{(11)}$, $Z \alpha=1.960$ untuk $\alpha=5 \%$, dan $Z \beta=0.842$ untuk $\beta=20 \%$, tetapi pada penelitian ini diambil 40 subjek yang berobat di salah satu rumah sakit swasta di Jakarta Pusat.

Tabel 1. Klasifikasi hipertensi

\begin{tabular}{lcc}
\hline \multicolumn{1}{c}{ Kategori } & $\begin{array}{c}\text { Tekanan } \\
\text { Darah Sistolik } \\
\text { mmHg }\end{array}$ & $\begin{array}{c}\text { Tekanan Darah } \\
\text { Diastolik } \\
\text { mmHg }\end{array}$ \\
\hline Normal & $\leq 120$ & dan $\leq 80$ \\
$\begin{array}{l}\text { Pre hipertensi } \\
\text { Hipertensi } \\
\text { derajat 1 }\end{array}$ & $120-139$ & atau $80-89$ \\
$\begin{array}{l}\text { Hipertensi } \\
\text { derajat 2 }\end{array}$ & $\geq 160-159$ & atau $90-99$ \\
$\begin{array}{l}\text { Hipertensi } \\
\text { sistolik } \\
\text { terisolasi }\end{array}$ & atau $\geq 100$ \\
$\begin{array}{l}\text { Keterangan: } \mathrm{mmHG}_{\mathrm{H}}=\mathrm{millimeter} \text { hydrargirum. Dikutip } \\
\text { dari : James et al. }{ }^{(12)}\end{array}$ &
\end{tabular}

Keterangan: $\mathrm{mmHG}=$ millimeter hydrargirum. Dikutip dari : James
Kriteria inklusi pada penelitian ini adalah pasien pria dan wanita usia 40-70 tahun, menderita hipertensi dengan kriteria seperti pada Tabel 1 dan terdapat data hasil pemeriksaan laboratorium albuminuria. Kriteria eksklusi pada penelitian ini adalah pasien dengan data rekam medis yang tidak lengkap, diabetes mellitus, penyakit jantung dan menderita infeksi saluran kemih.

Pemeriksaan albuminuria dilakukan dengan tes dipstick. Tes dipstick menggunakan prinsip kromatografi untuk mendeteksi adanya albumin di urin. Tes disebut negatif bila didapatkan albuminuria $<150 \mathrm{mg} /$ hari; positif 1: $200-500 \mathrm{mg} /$ hari; positif 2: $500-1500 \mathrm{mg} /$ hari dan positif 3: $>2.5 \mathrm{~g} /$ hari. Analisa statistik dilakukan dengan uji korelasi Spearman dengan tingkat kemaknaan $\mathrm{p}<0.05$. Penelitian ini telah lolos kaji etik dari Tim Kaji Etik Universitas Trisakti dengan no. 115/ KER-FK/X/2015.

\section{HASIL}

Karakteristik subjek penelitian tersebut dapat dilihat pada Tabel 2.

Tabel 2. Karakteristik subjek penelitian

\begin{tabular}{lc}
\hline \multicolumn{1}{c}{ Karakteristik } & n (\%) \\
\hline Usia $(\mathbf{X} \pm \mathrm{SD})$ (tahun) & $56.2 \pm 4.5$ \\
Kategori Usia & \\
$40-49$ & $11(27.5)$ \\
$50-59$ & $14(37.5)$ \\
$\geq 60$ & $15(35)$ \\
Jenis Kelamin & \\
Pria & $20(50)$ \\
Wanita & $20(50)$ \\
Tekanan darah & \\
Sistolik (X \pm SD) (mmHg) & $151.4 \pm 20.3$ \\
Diastolik (X \pm SD) (mmHg) & $93.1 \pm 7.6$ \\
Kategori hipertensi & \\
Pre hipertensi & $8(20)$ \\
Derajat 1 & $12(30)$ \\
Derajat 2 & $15(37.5)$ \\
Sistolik terisolasi & $5(12.5)$ \\
Albuminuria & \\
Negatif & $20(50)$ \\
Positif 1 & $6(15)$ \\
Positif 2 & $10(25)$ \\
Positif 3 & $4(10)$ \\
Keterangan: X=rerata, SD=standar deviasi, \\
mmHg=millimeter hydrargirum \\
\end{tabular}

Tabel 2 menunjukkan rerata usia subjek adalah 56.2 \pm 4.5 tahun. Subjek dengan usia 50-59 tahun merupakan subjek terbanyak yaitu sebanyak 15 orang $(37.5 \%)$. Berdasarkan jenis kelamin 
didapatkan jumlah yang sama besar, yaitu dengan jenis kelamin pria sebanyak 20 orang $(50 \%)$ dan wanita sebanyak 20 orang (50\%). Rerata tekanan darah sistolik subjek adalah $151.4 \pm 20.3 \mathrm{mmHg}$ dan tekanan darah diastolik adalah 93.1 \pm 7.6 mmHg. Berdasarkan derajat hipertensinya persentase terbanyak yaitu hipertensi derajat 2 sebanyak 15 orang $(37.5 \%)$. Berdasarkan ada tidaknya albuminuria pada subjek penelitian didapatkan pasien dengan albuminuria negatif merupakan jumlah yang terbanyak yaitu sebanyak 20 orang $(50 \%)$.

Tabel 3. Distribusi usia dan jenis kelamin berdasarkan albuminuria

\begin{tabular}{lccc}
\hline & \multicolumn{2}{c}{ Albuminuria (n) } & \multirow{2}{*}{$\boldsymbol{p}$} \\
\cline { 2 - 3 } & Negatif & Positif & \\
\hline Usia & 5 & 6 & \\
40-49 tahun & 6 & 9 & 0.400 \\
$50-59$ tahun & 9 & 5 & \\
$\begin{array}{l}\text { 60 tahun } \\
\text { Jenis Kelamin }\end{array}$ & & & \\
Pria & 12 & 8 & 0.206 \\
Wanita & 8 & 12 & \\
\hline
\end{tabular}

Keterangan: $\mathrm{p}<0.05$ berbeda bermakna (Uji Chi Square)

Distribusi albuminuria berdasarkan usia dan jenis kelamin disajikan pada Tabel 3. Berdasarkan analisa statistik menggunakan uji Chi Square tidak terdapat perbedaan bermakna antara derajat albuminuria dengan usia maupun dengan jenis kelamin dengan nilai $p$ berturut-turut 0.400 dan 0.206 .

Tabel 4. Distribusi responden dengan hipertensi dan albumunuria

\begin{tabular}{lccc}
\hline \hline & \multicolumn{2}{c}{ Albuminuria (n) } & \multirow{2}{*}{$\boldsymbol{p}$} \\
\cline { 2 - 3 } & Negatif & Positif & \\
\hline Pre hipertensi & 7 & 1 & \\
Hipertensi derajat 1 & 8 & 4 & $0.001^{*}$ \\
Hipertensi derajat 2 & 1 & 14 & \\
Hipertensi sistolik & 4 & 1 & \\
\hline Keterangan: p $<0.05$ berbeda bermakna (Uji Fisher), \\
*=berbeda bermakna
\end{tabular}

Tabel 4 memperlihatkan nilai albuminuria berdasarkan derajat hipertensi. Jumlah distribusi subjek terbanyak yaitu subjek dengan hipertensi derajat 2 sebanyak 15 orang (37.5\%), sedangkan subjek dengan nilai albuminuria positif terbanyak juga pada hipertensi derajat 2 yaitu sebanyak 13 orang (32.5\%). Berdasarkan uji Fisher antara derajat hipertensi dan albuminuria terdapat perbedaan bermakna dengan nilai $\mathrm{p}=0.0001$.

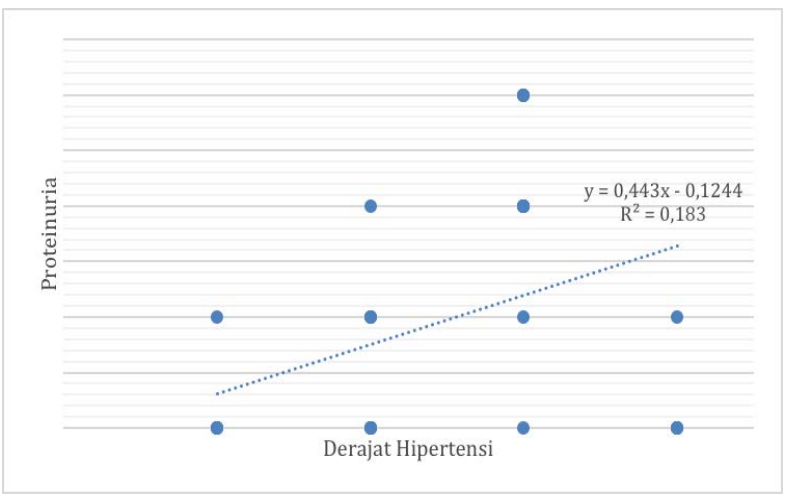

\section{Gambar 1. Korelasi antara hipertensi dengan albuminuria}

(Uji Spearman dengan $\mathrm{r}=0.428 ; \mathrm{p}=0.006$ )

Gambar 1 menunjukkan korelasi antara hipertensi dengan albuminuria. Antara hipertensi dengan albuminuria terdapat korelasi positif yang bermakna $(\mathrm{r}=0.428, \mathrm{p}=0.006)$. Makin tinggi derajat hipertensi seseorang maka makin besar kadar albuminuria.

\section{PEMBAHASAN}

Urinalisa lengkap merupakan tes urin yang sederhana dan murah, serta dapat dijadikan landasan dalam evaluasi fungsi ginjal. Penyakit ginjal yang serius dapat diderita tanpa gejala klinis yang jelas. Albuminuria serta hematuria mungkin merupakan satu-satunya tanda-tanda awal penyakit ginjal. Pemeriksaan albuminuria dengan menggunakan dipstick adalah prosedur penyaring yang paling cepat yang dapat membantu deteksi dini penyakit saluran ginjal atau kemih antara subjek yang tampak sehat atau tanpa gejala dengan harapan mencegah dan memperlambat perkembangan PGK. ${ }^{(13)}$ Tingginya tekanan darah dapat merusak pembuluh darah ginjal yang berfungsi untuk menyaring darah dan membuang sisa sisa metabolisme yang ada di dalam tubuh. $(14,15)$

Kejadian albuminuria pada penderita hipertensi berhubungan dengan kerusakan pada endotel glomerulus dan merupakan prediktor penyakit kardiovaskular. ${ }^{(16)}$ Dalam perawatan primer pemeriksaan dengan tes dipstick pada pasien yang baru didiagnosis hipertensi dapat menunjukkan adanya mikroalbuminuria dengan spesifisitas yang tinggi. Urinalisa lengkap dengan metode dipstick dapat menjadi metode screening yang dapat diandalkan untuk diagnosis infeksi 
saluran kemih dan diabetes mellitus. Sensitivitas yang rendah pada proteinuria, maka standar tes dipstick urin tidak dapat direkomendasikan sebagai metode tunggal skrining untuk kerusakan organ target ginjal. ${ }^{(17)}$

Istilah proteinuria dan albuminuria sering disamakan dalam literatur medis, karena pada umumnya protein urin yang paling banyak pada pasien dengan penyakit ginjal adalah albumin. Namun, harus diingat bahwa dipstick standar hampir secara eksklusif sensitif terhadap albumin. Pada orang dewasa dalam keadaan normal mengekskresikan kurang dari 150 sampai 200 $\mathrm{mg} / \mathrm{d}$ protein dalam urin. Sebagian kecil dari protein ini adalah albumin. Ekskresi Albumin dalam kisaran 30 sampai $300 \mathrm{mg} / \mathrm{d}$ disebut sebagai mikroalbuminuria. ${ }^{(18)}$

Penelitian ini dilakukan pada subjek yang berusia 40 sampai 70 tahun dengan jumlah responden terbanyak berusia antara 50-59 tahun yang mengalami albuminuria yaitu sebanyak 15 orang (37.5\%) (Tabel 2). Pada penelitian Herrera $\mathrm{R}$ et $\mathrm{al} \mathrm{l}^{(16)}$, diambil data subjek dengan albuminuria pada usia 20-70 tahun dan didapatkan subjek dengan jumlah terbanyak berusia 60-69 tahun yaitu sebanyak 101 orang (15.5\%). Penelitian Gupta et $\mathrm{al}^{(19)}$ diambil data subjek dengan proteinuria pada usia 40-79 tahun. Penelitian tersebut mendukung penelitian ini bahwa nilai albuminuria yang tinggi didapatkan pada grup usia terbesar yaitu 60-79 tahun. Menurut penelitian Buranakitjaroen et $\mathrm{al}^{(20)}$ di Thailand, albuminuria ditemukan dengan jumlah terbanyak pada populasi usia yang lebih tua. Berdasarkan penelitian Rosas et $\mathrm{al}^{(21)}$ ditemukan bahwa terdapat hubungan antara albuminuria dengan derajat hipertensi dan usia. Data dari National Health and Nutrition Examination Survey study (NHANES) menunjukkan bahwa albuminuria dijumpai pada $4 \%$ dari pria dan $2 \%$ dari wanita usia 45 hingga 74 tahun. Data dari the Framingham Heart Study melaporkan prevalensi albuminuria pada pasien usia lanjut sebesar 17.4\% dari pria dan $12.9 \%$ dari wanita pada keadaan basal. ${ }^{(22)}$

Berdasarkan jenis kelamin subjek, pada penelitian ini didapatkan albuminuria positif terbanyak pada wanita yaitu 12 orang $(30 \%)$ sedangkan pada pria 8 orang $(20 \%)$, tetapi tidak berbeda bermakna secara statistik dengan nilai $p=0.206$ (Tabel 3). Hasil penelitian ini didukung oleh penelitian Herrera et $\mathrm{al}^{(16)}$ yang melaporkan jumlah subjek dengan albuminuria positif pada pria $12.7 \%$ dan pada wanita $11.4 \%$. Demikian juga penelitian Takase et al ${ }^{(23)}$ melaporkan bahwa subjek terbanyak dengan albuminuria yaitu pada pria $4.6 \%$ sedangkan pada wanita $3.2 \%$. Penelitian Won et $\mathrm{al}^{(24)}$ juga mendukung penelitian ini bahwa antara jenis kelamin dan albuminuria tidak terdapat perbedaan bermakna dengan nilai $\mathrm{p}=0.114$. ${ }^{(24)}$

Hasil penelitian ini menunjukkan bahwa usia tidak menunjukkan perbedaan bermakna secara statistik dengan albuminuria (Tabel 3) dengan nilai $\mathrm{p}=0.400$. Penelitian Buranakitjaroen et $\mathrm{al}^{(20)}$ melaporkan bahwa hanya parameter usia $\geq 45$ tahun pada laki-laki atau $\geq 55$ tahun pada wanita yang menunjukkan perbedaan bermakna secara statistik dengan kadar mikroalbuminuria $(\mathrm{p}=0.03)$, tetapi tidak dengan makroalbuminuria. (20) Perbedaan hasil penelitian Won et $\mathrm{al}^{(24)}$ dan penelitian ini mungkin disebabkan perbedaan usia subjek yang digunakan yaitu melibatkan subjek usia dibawah 40 tahun. ${ }^{(24)}$

Berdasarkan perbedaan derajat hipertensi dengan albuminuria didapatkan jumlah terbanyak pada subjek dengan hipertensi derajat 2 sebanyak 15 orang $(37.5 \%)$. Antara derajat hipertensi dan albuminuria terdapat perbedaan bermakna dengan nilai $\mathrm{p}=0.001$ (Tabel 4). Penelitian Won et $\mathrm{al}^{(24)}$ melaporkan hal yang sama yaitu didapatkan perbedaan bermkna antara derajat hipertensi dan albuminuria dengan nilai $\mathrm{p}<0.001$. $^{(24)}$ Penelitian Herrera et $\mathrm{al}^{(16)}$ melaporkan bahwa prevalensi terbanyak penderita dengan albuminuria adalah kategori prehipertensi (11\%). Perbedaan data pada kedua hasil penelitian ini disebabkan penelitian Herrera et al $^{(16)}$ mengambil data dari subjek dengan PGK yang rajin melakukan skrining aktif, terkontrol dan kemungkinan subjek tersebut didahului dengan PGK yang diikuti dengan hipertensi. Beberapa penelitian mampu menunjukkan efek pengurangan albuminuria pada perkembangan CKD melalui kontrol tekanan darah. Selain karena efek pengobatan, nilai proteinuria dapat bervariasi pada tiap individu yaitu pada keadaan trauma, infeksi saluran kemih, peningkatan produksi protein di tubuh pada beberapa penyakit seperti multipel mieloma dan amiloidosis, preeklamsia, hiperglikemia, gagal jantung, demam, dan kegiatan yang intens. ${ }^{(25)}$ 
Korelasi antara hipertensi dan albuminuria menunjukkan hubungan positif dengan korelasi sedang (Gambar 1) dengan $\mathrm{r}=0.428$ dan $\mathrm{p}=0.006$. Hasil ini menunjukkan bahwa urinalisa albumin dapat digunakan sebagai pemeriksaan penunjang pada penderita hipertensi yang merupakan petanda adanya komplikasi ke organ ginjal. Penelitian Tenekecioglu et $\mathrm{al}^{(11)}$ menunjukkan hasil yang mendukung penelitian ini yaitu terdapat korelasi antara hipertensi dan albuminuria $(\mathrm{r}=0.696$ dan $\mathrm{p}=<0.001) .{ }^{(11)}$ Barbour et $\mathrm{al}^{(26)}$ melaporkan bahwa pemeriksaan albuminuria merupakan prediktor terbaik adanya gangguan ginjal. Dilaporkan juga pentingnya standarisasi waktu pengambilan urin untuk menetapkan albuminuria sebagai surrogate marker untuk fungsi ginjal. ${ }^{(26)}$ Implikasi penelitian ini adalah bahwa diperlukan pemeriksaan tekanan darah secara rutin dan pemeriksaan urinalisis yang mencakup adanya tes albuminuria sebagai skrining pada pasien yang berusia di atas 40 tahun karena dapat mengetahui kemungkinan adanya hipertensi atau penyakit lainnya yang menyebabkan terjadinya albuminuria, mengingat banyaknya pasien dengan hipertensi yang tidak menyadari bahwa dirinya menderita hipertensi. Keterbatasan penelitian ini adalah data yang digunakan adalah data sekunder sehingga tidak diketahui berapa lama pasien sudah menderita hipertensi dan waktu pengambilan sampel urin untuk pemeriksaan albuminuria tidak dapat distandarisasi.

\section{KESIMPULAN}

Sebagai kesimpulan terdapat korelasi yang bermakna antara hipertensi dengan albuminuria yang menunjukkan bahwa semakin besar nilai tekanan darah pada pasien hipertensi akan memengaruhi organ ginjal sehingga menyebabkan terjadinya albuminuria.

\section{KONFLIK KEPENTINGAN}

Penulis menyatakan tidak ada konflik kepentingan.

\section{UCAPAN TERIMA KASIH}

Peneliti mengucapkan terima kasih kepada pihak RS Moh. Ridwan Meuraksa yang telah memberikan izin dilakukannya pengambilan data untuk penelitian ini.

\section{DAFTAR REFERENSI}

1. Sawicka K, Szczyrek M, Jastrzebska I, et al. Hypertension-the silent killer. JPCCR 2011;5:435.

2. Kesehatan Kementrian Kesehatan RI. Riset Kesehatan Dasar. Laporan Kesehatan RI. Jakarta. 2013.p.88-9.

3. Lionakis N, Mendrinos D, Sanidas E, et al. Hypertension in the elderly. World $J$ Cardiol 2012;4:135-8. doi: 10.4330/wjc.v4.i5.135.

4. Ravera M, Re M, Deferrari L, et al. Importance of blood pressure control in chronic kidney disease. J Am Soc Nephrol 2006; 17:S98-103. doi:10.1681/ ASN.2005121319.

5. Viazzi F, Pontremoli R. Blood pressure, albuminuria and renal dysfuntion: the "chicken or egg' dilemma. Nephrol Dial Transplant 2014;29:1453-5. doi:10.1093/ndt/gfu183.

6. National Institute of Diabetes and Digestive and Kidney Diseases. Proteinuria. National Institutes of Health, U.S. Department of Health and Human Services 2014.

7. Koroshi A. Microalbuminuria, is it so important? Hippokratia 2007;11:105-7.

8. Zhang A, Huang S. Progress in pathogenesis of proteinuria. Int $\mathrm{J}$ Nephrol 2012;26:1-15. doi:10.1155/2012/314251.

9. Yoon SY, Kim DH, Nam GE, et al. Prevalence and control of hypertension and albuminuria in South Korea: Focus on obesity and abdominal obesity in the Korean National Health and Nutrition Examination Survey, 2011-2012. Plos One 2014;9:e111179. doi:10.1371/journal. pone. 0111179 .

10. Jessani S, Levey AS, Chaturverdi $\mathrm{N}$, et al. High normal levels of albuminuria and risk of hypertension in Indo-Asian population. Nephrol Dial Transplant 2010:27(supple 3):iii58-64. doi:10.1093/ndt/gfr200.

11. Tenekecioglu E, Yilmaz M, Yontar OC, et al. Microalbuminuria in untreated prehypertension and hypertension without diabetes. Int J Clin Exp Med 2014;7:3420-9.

12. James PA, Oparil S, Carter BL, et al.. Evidence based guideline for the management of high blood pressure in adults report from the panel members appointed to eighth joint national committee (JNC 8). JAMA 2014;311:507-20. doi: 10.1001/ jama.2013.284427

13. Hajar F, Taleb M, Aoun B, et al. Dipstick urine analysis screening among asymptomatic school children. N Am J Med Sci 2011;3:179-84. doi:10.4297/najms.2011.3179.

14. Sarafidis PA, Khosla N, Bakris GL. Antihypertensive therapy in the presence of proteinuria, Am J Kidney Dis 2006;49:12-26. doi: 10.1053/j.ajkd.2006.10.014.

15. Intermountain Healthcare. Kidney disease, high blood pressure, and urine proteins. Available at: http://intermountainhealthcare.org/ext/ Dcmnt?ncid=521463549. Accessed May 15,2015.

16. Herrera R, Almaguer M, Chipi J, et al. Albuminuria as a marker of kidney and cardio-cerebral vaskular damage. MEDICC Rev 2010;12:20-6.

17. Zamanzad B. Accuracy of dipstick urinalysis as a screening method for detection of glucose, protein, nitrites and blood. Eastern Mediterr Health J 2009;15:1323-8.

18. Venkat KK. Proteinuria and microalbuminuria in 
adults: significance, evaluation, and treatment. South Med J 2005;97:969-79. doi: 10.1097/01. SMJ.0000140833.5153.46.

19. Gupta A, Pal A, Nelson S. Study of microalbuminuria in hypertension. Int J Sci Stud 2015;3:32-9.

20. Buranakitjaroen P, Phoojaroenchanachai M, Savarich S. Microalbuminuria in Thai essential hypertensive patients. J Int Med Res 2007;35:83647. doi:10.1177/147323000703500612.

21. Rosas M, Attie F, Pastelin G, et al. Prevalance of Proteinuria in Mexico : A conjunctive consolidation approach with other cardiovascular risk factors: the Mexican health survey 2000. Kidney Int 2005;68:S112-9.

22. Kopyt NP, Reed JF. Prevalence of proteinuria in the U.S adult population : result from NHANES surveys (2001-2004). Am J Kidney Dis 2008;51:B58-79.

23. Takase H, Sugiura $\mathrm{T}$, Ohte $\mathrm{N}$, et al. Urinary albumin as a marker of future blood pressure and hypertension on the general population. Medicine 2015;94:1-7. doi: 10.1097/ MD.0000000000000511.

24. Won JC, Lee YJ, Kim JM, et al. Prevalence of and factors associated with albuminuria in the Korean adult population: The 2011 Korea national health and nutrition examination survey. Plos One 2013;8:e83273. Doi:10.1371/journal. pone. 0083273 .

25. Pedrinelli R, Bell OG, Di Bello V, et al. Microalbuminuria, an integrated marker of cardiovascular risk in essential hypertension. J Human Hypertens 2005;16:79-89.

26. Avasare RS, Radhakrishnan J. Proteinuria as a surrogate marker for renal outcome: are we there yet? Kidney Int 2015:88;1228-30.doi:10.1038/ ki.2015.301. 